\title{
Cheques Sem Fundos
}

\section{ARNOLD WALD}

E

M artigo publicado na "Revista do Serviço Público" de abril de 1953 e que foi posteriormente transcrito no Boletim das Caixas Econômicas, tivemos o ensejo de assinalar a indiferença dos tribunais em relação ao crime de emissão de cheques sem fundos e a interpretação excessivamente liberal e injustificada que era dada ao artigo 171 do Código Penal no inciso referente aos cheques.

Esta matéria vinha a ter revelância econômica pelo curso dado a uma moeda na realidade inexistente e importava mesmo para a administração pública num prejuízo sério já que esta aceitava os cheques em pagamento. de conformidade com leis especiais destinadas a facilitarem a circulação monetária pelo emprêgo do cheque.

A campanha assim iniciada já teve uma primeira repercussão no louvável ato do Excelentíssimo Desembargador Corregedor da Justiça, Dr. Mário Guimarães Fernandes Pinheiro, que houve por bem, em portaria por êle baixada, mandar que todos os cheques protestados por falta de pagamento fôssem ex-lege encaminhados à Procuradoria Geral do Distrito Federal para início do respectivo processo. A providência tomada merece os maiores aplausos, acabando assim com a epidemia generalizada de cheques sem fundos a que assistíamos diante da impunidade assegurada pela inercia judicial aos emitentes.

E' preciso que o exemplo dado pelo Corregedor seja seguido pelos juízes criminais voltando-se à punição do crime de emissão de cheque sem fundo, que representa uma lesão de direito individual e um perigo econômico para a sociedade, como crime formal que é. 